\title{
Islamic Perspective on Family Planning
}

\section{Najimudeen $M^{*}$}

International Medical School, Management \& Science University, Malaysia

\begin{tabular}{ll}
\hline DOI: $10.36348 /$ sijog.2020.v03i03.006 & | Received: 03.03.2020 | Accepted: 10.03 .2020 | Published: 21.03 .2020
\end{tabular}

*Corresponding author: Najimudeen $\mathrm{M}$

\section{Abstract}

The most remarkable demographic features in Islamic societies are the high level of fertility and high unmet demand of contraception. Reproductive health is a matter of discussion among the Islamic countries for the last 40-50 years. Family planning (FP) is a subject of controversy over the Muslim world. Contraceptive prevalence rate among Muslim countries are relatively low compared to rest of the world. Muslims fear that the FP methods are Western intended programme to control the Muslim population .They also fear that the contraceptive methods could be a form of infanticide. This article critically analyse the truth and myths about family planning methods in the Islamic perspective. There is not a single text in the Quran to prohibit the use of contraceptive methods. In fact Islam endorses and encourages the practice of spacing.

Keywords: Contraceptives, Family planning, Islam, Muslim countries.

Copyright @ 2020: This is an open-access article distributed under the terms of the Creative Commons Attribution license which permits unrestricted
use, distribution, and reproduction in any medium for non-commercial use (NonCommercial, or CC-BY-NC) provided the original author and source
are credited.

\section{INTRODUCTION}

Family planning (FP) is a subject of controversy not only in Malaysia but all over the Muslim world. Contraceptive prevalence rate among Muslim countries are relatively low compared to rest of the world. Muslims fear that the FP methods are Western intended programme to control the Muslim population. They also fear that the contraceptive methods could be a form of infanticide. This article critically analyse the truth and myths about family planning methods in the Islamic perspective. There is not a single text in the Quran to prohibit the use of contraceptive methods. In fact Islam endorses and encourages the practice of spacing the families.

\section{METHODOLOGY}

The texts in Quran, the words of prophet Mohamed (Hadis), the life of the companions of prophet, Fatwa (Islamic rulings) given by Islamic scholars, proceedings of the conferences in Islam and family planning were analysed.

\section{DISCUSSION}

The global Contraceptive prevalence rate (CPR) for all forms of contraception is $64 \%$. The CPR for United kingdom $84 \%$, Norway $82 \%$, Canada $80 \%$ but in Islamic countries like Oman $18 \%$, Somalia $14 \%$ and Sudan $11 \%$ [1].

The most remarkable demographic features in Islamic societies are the high level of fertility and high unmet demand of contraception.

Around $77 \%$ maternal deaths of the Arab region mainly occur in three countries namely Sudan, Somalia and Yemen. The notable feature in these three countries compared to other Arab countries are the lowest use of contraceptive practice [2].

Does Islam prohibits family planning measures? FP are the methods to space the family and to avoid unintended pregnancies.

\section{Islamic Perspective}

The only family planning method available during the era of Prophet Mohamed 1440 years back was coitus interruptus, popularly known as withdrawal method. In this method the male organ is taken out of vagina just prior to ejaculation. This called in Arab as 'Azl' Jabir Ibn Abdullah, a companion of prophet Mohamed narrates 'We were practising azl. Prophet had known our practice but he had not prevented us [3]. 
Muslim scholars belonging to Islamic schools such as Hanafi, Shafi, Maliki and Jafaris had endorsed the practice of al -azl with the consent of the wife. Some of the Imams are of opinion that the consent of the wife is not necessary [4].

Some other scholars of the Prophet's (pbuh) tradition, like Ibn Majah and Ahmad, agreed that coitus interruptus was permitted by the Prophet (pbuh) [5].

Shayakh Abd Allah Al-Qalqili, the Grand Mufti of Jordan had issued a fatwa in the year 1964 stating that most of the jurisprudence agree that coitus interruptus is permissible. Medication to prevent the conception and induce abortion is very pregnancy are acceptable [6].

The oral contraceptive pills (OCP) injectable preparations, implants and intra uterine contraceptive devices (IUCD) prevent the union of spermatozoa and ovaum. These are analogue to the Azl method. Therefore these are permitted in Islam

Sheik Yusuf as - Qaradawi, a professor of Islamic studies in Qatar University in the year 1980 stated the modern contraceptive methods are analogous to azl. Therefore they are permitted [7].

\section{Natural Method of Prevention of Conception}

The female egg (Ovum) is viable only for 24 hours and the spermatozoa is viable only for 48 hours in the female genital tract. Two days before and after the ovulation ( 5 days window) are the fertile days. If we can get the date of ovulation, we can avoid these 5 days we can prevent conception. This is also a natural way of spacing the family.

Just before the release of the female egg from the ovary (prior to the ovulation), a large amount of hormone named luteinizing hormones (LH) is produced. This is known as an "LH surge". This high level of LH can be detected by simple testing of urine. This test is named as Ovulation Test.

This test is freely available in most of the countries and this is a simple way to prevent conception.

\section{Barrier Methods}

The Male and female condoms are popular methods to prevent the pregnancy. In addition to prevent the conception they have the added advantage of preventing the sexually transmitted infections.

What about the permanent surgical sterilisation? If the future pregnancy would endanger the life of the mother, one of the couple can perform permanent contraceptive method.

\section{Negative approach}

Why some of the Muslims oppose FP methods. They quote 2 phrases from Holy Quran. Those verses are as follows:

Say, "Come, I will recite what your Lord has prohibited to you. [He commands] that you not associate anything with Him, and to parents, good treatment, and do not kill your children out of poverty; we will provide for you and them. And do not approach immoralities - what is apparent of them and what is concealed. And do not kill the soul which Allah has forbidden [to be killed] except by [legal] right. This has He instructed you that you may use reason." (Al Quran $6: 151)$

And do not kill your children for fear of poverty. We provide for them and for you. Indeed, their killing is ever a great sin. ((Al Quran 17:31)

These 2 phrases prohibit the killing of children in fear of poverty. The FP methods are not killing the children. These phrases warn the people killing their children as selective infanticide of female foetus in the current era, criminal abortion of the formed foetus and killing the new born females in the yester era of Prophet's time. The Quran had prohibited only these brutal acts. Unfortunately these phrases are misinterpreted

In no way does this verse refer to family planning because it is talking of 'killing' and you kill one who exists. Spermatozoa and egg cannot survive on their own and preventing their union is not killing.

"Then we made the sperm-drop into a clinging clot, and we made the clot into a lump [of flesh], and we made [from] the lump, bones, and we covered the bones with flesh; then we developed him into another creation. So blessed is Allah, the best of creators." (Al Quran 23:14). Kalipah Ali (Rali) explained this phrase as the life begins only at the stage of another creation (Halkan aahar). Therefore the prevention of meeting the sperm and the ovum is not infanticide

\section{Are the FP methods minor infanticides?}

Abu Said had once asked the prophet "The Jews say that coitus interruptus is minor infanticide, and the Prophet (pbuh) answered, 'The Jews lie, for if God wanted to create something, no one can avert it (or divert Him) [8].'

In the book titled Ihya ulum al Din (The revival of religious sciences, Imam al-Ghazzali had differentiated infanticide and contraception very clearly. Pure emission of spermatic fluid alone cannot produce an infant. Therefore prevention before forming the zygote cannot be considered as an infanticide [9]. 
Some of the companions told the Prophet that the Jews are of the view that the family planning is minor infanticide - Mawoodathu sahree and asked his opinion. The Prophet replied that these methods are not minor infanticide but if Allah decides to create, no one can prevent it. This is clearly proves that family planning methods are not infanticides ${ }^{(10)}$

\section{Western Agenda}

Is the FP methods are the hidden Western agenda to reduce the Muslim population?

The contraceptive prevalence rate (CPR) for modern methods in Finland is $81 \%$ and in France $75 \%$, Netherland $74 \%$ and New Zealand is $72 \%$ whereas the CPR for Afghanistan is $19.8 \%$. Libya $20 \%$, and UAE $23 \%$ [11].

From this data, it is very clear that the CPR is very high among the Western world compared to the Muslim countries. Therefore it is very obvious that the FP methods are not the vested interest of the Western countries to reduce the Muslim population.

Islamic scholars had endorsed the use of temporary birth control methods for the purpose of spacing the pregnancies [12].

Family planning was once discussed among the companions of Prophet. Ali ibn Ab Thaalib read AlQuran chapter 23 verses 12, 13 and 14. And certainly did we create man from an extract of clay. Then we placed him as a sperm-drop in a firm lodging. Then we made the sperm-drop into a clinging clot, and we made the clot into a lump [of flesh], and we made [from] the lump, bones, and we covered the bones with flesh; then we developed him into another creation. So blessed is Allah, the best of creators. (23:12-14) Life (Ruh) is given many days after fertilization. Therefore prevention of fertilization is not killing. Omar ibn Kathab also endorsed this view [13].

Scholars representing various schools of thought at the Majma alFiqh al-Islaami concluded that: "it is permissible to control the timing of births with the intent of distancing the occurrences of pregnancy or to delay it for a specific amount of time, based on mutual consultation and agreement between the couple" [14].

A leading proponent of this view is al-Ghazali (d. 1111), who bases his conclusions on the wellestablished principle that what is not prohibited by the Quranic text or an authenticated Hadith (words of the Prophet), or by analogical reasoning with respect to either or both, is permissible [15].
Imam Sheik Jadal Al Haq, Chief Imam of Al Azhar Egypt had confirmed that there is not a single verse in the Quran prohibiting family planning [16].

Great Islamic scholars of many countries have favoured family planning methods. Mufti Sheik Abdullah Al Qalqili of Jordan, Ayathullah Haj Sheik Bahaeddin Mahallati of Iran, Mufti Al Seyed Yoosuff Ibn Al Zavafi of Malaysia and Yusuf Al Qaradavi are some of them. Sheik Hassan Manoon of Al Azhar University had clearly stated that Islam permits contraceptive practice. Morocco conference of 1971 published a book named Islam and family planning.

Reproductive health is a matter of discussion among the Islamic countries for the last 40-50 years. From the Rabat conference in 1971 on Islam and family planning to Indonesian congress in the year 1990 the subject of FP was discussed extensively. Islamic countries such as Egypt, Morocco, Bangladesh and Indonesia were trying to implement programmes suitable for their countries. The International Conference on Population and Development (ICPD) (the 'Cairo Agreement') in the year 1994 made a remarkable progress in the FP [17].

Temporary FP methods are permissible for health and economic reasons [18].

Mufti Haji Abdel Jalil Hassan of Malaysia (1965) has allowed temporary family planning methods [19].

Sheik Sharwi, a well known Arabic scholar has stated that FP is allowed in Islam to protect the health of the mother, maintain her beauty and overcrowding the house [20].

Imam Zabidi states that FP methods are not against Islam. He endorsed the view of Imam Gazali that FP methods can be advocated for economic reasons [21].

\section{CONCLUSION}

There is not single text in the Quran to prohibit the practice of family planning methods. The Prophet Mohamed had never discouraged the family planning methods. The Islamic scholars has endorsed the use of these methods. Most Islamic countries endorsed the Programme of Action of the United Nations 1994 International Conference on Population and Development, and the 2000 Millennium Development Summit Declaration which called for universal access to FP information and services. 
The religion hardly plays major role. The religion is not a major factor in preventing the women from seeking family planning services. Misperceptions and misconceptions should be eliminated.

\section{REFERENCE}

1. UN data on CPR. (2017). Department of economic and social affairs Population division. World CPR.

2. Makhlouf Obermeyer. (2015). DIFI Family Research and Proceedings: 1.

3. Naisaburi, Muslim ibn al Hajjaj: Sahih Muslim, 1: 465.

4. Wahbah al-Zuhaili. (1984). Al-Fiqh al-Islami wa Addillatuh (Dar al-Fikr, Damascus), 7:331-332.

5. Khan, A. H. (1987). Zabate Tauleed Key Baray Mein Islami Nazariyat (in Urdu), Population Welfare Division, Government of Pakistan.

6. Gupte, P. (1984). The Crowded Earth, People and Politics of Population (New York: W.W. Norton and Co. 349.

7. Omran, A. R. (1992). Family Planning in the Legacy of Islam. London, UK: Routledge.

8. Musallam, B. F. (1983). Sex and Society in Islam, Cambridge University Press, 176.

9. Al-Ghazzali, Ihya' Ulum al-Din, Al Matba alAzhariyya al-Misriyya (Cairo, 1302 A.H.).

10. Muhammad Ibn 'Elsa Sunan At-Tirmidhi. 2:135.
11. United Nation Department of Economic and social affairs Population division (2018).

12. Omran. (1992). Family planning in the legacy of Islam. Routledge publication, 133.

13. Proceedings of the session of the Islamic Fiqh Council held during its fifth conference in Kuwait, 1-6 Jumaada al-Aakhir 1409 AH/10-15 December $1988 \mathrm{AH}$.

14. Najat El Hamri. (2010). Approaches to family planning in Muslim communities. Journal Fam Plann Reprod Health Care, 36(1):29.

15. Abu Hamid, M. (1939). al-Ghazali, 'Ihya' Ulum alDin (reprint, Mustafa al-Babi al-Halabi wa awladuhu, Cairo, 2:53.

16. Sheik Jadal Ali Jadel Haq. (1991). Law of Sharia in Gynaecological problems (Monograph) published by Al Azhar Cairo.

17. Jadel Haq. (1980). Fatwa on family planning in Islam. Al Fatwa al Islamiyyah, 29:3110-3113

18. Saleem Sheik Abdul Majeed. (1937). Journal of Egyptian medical association, 20(7):55.

19. Hassan Haji Abdel Jalil Bin Haji Hassan: Fatwa Uustan Malaysia (21.11.1965)

20. Sharawi Sheik Muhammad Mitwalli: Rabat proceeding of IPPF (1974) Vol. 2 page 5-28

21. Zabidi. (1970). Ithaf al sadah at muthaqin Fi Shah Ihya Ulum at Din Dar Ihya al Thurathal Arabia, 5:378-384. 